\title{
Hybridization of Cultivated Highbush Blueberry with Vaccinium stamineum: Phenotype and Fertility of Backcross 1 Populations
}

\author{
Paul M. Lyrene ${ }^{1}$ \\ Department of Horticultural Sciences, University of Florida, Gainesville, FL \\ 32611
}

Additional index words. deerberry, wide hybridization, polyploidy, evolution, plant breeding

\begin{abstract}
Nine $\mathrm{F}_{1}$ hybrids produced by crossing seven tetraploid highbush blueberry cultivars with three tetraploid Vaccinium stamineum genotypes were backcrossed to an array of highbush blueberry cultivars to produce 2500 Backcross $_{1}\left(B_{1}\right)$ seedlings. Thirty of the most vigorous $\mathrm{BC}_{1}$ plants were intercrossed in a greenhouse. Fertility of the $\mathrm{BC}_{1}$ plants was studied by examining their pollen at $250 \times$ and by determining the number of well-developed seeds per pollinated flower after the crosses. Percent wellformed microspores averaged $62.7 \%$ for $\mathrm{BC}_{1}$ plants compared with $30.9 \%$ for their $\mathrm{F}_{1}$ hybrid parents. Fruit set percentage was high from the $\mathrm{BC}_{1}$ intercrosses, with an average of 9.29 plump seeds per pollinated flower. The $2500 \mathrm{BC}_{1}$ seedlings in the field were highly variable in vigor, but fewer than $10 \%$ were as vigorous as the median vigor of highbush $x$ highbush seedlings. $\mathrm{BC}_{1}$ plants in the field averaged $\approx 1$ month later ripening than highbush $\times$ highbush seedlings and berries averaged slightly smaller. Berry clusters were very loose compared with those of highbush. Berry flavor was highly variable from plant to plant, but the berries averaged less sweet and lower in acid than highbush berries. New flavor components not found in highbush seedlings were found in only a few $\mathrm{BC}_{1}$ seedlings. Fresh berries from $\mathrm{BC}_{1}$ plants made bright red juice when crushed in water, whereas berries from most highbush cultivars produced brown to yellow juice/ water mixes. Although berry quality in the $\mathrm{BC}_{1}$ population averaged lower than in highbush seedlings, some plants had berry quality as high as typical cultivars. Because $V$. stamineum is highly drought-tolerant, cultivars bred using $V$. stamineum introgression could have improved upland adaptation.
\end{abstract}

Vaccinium stamineum (deerberry), a highly polymorphic diploid species, is the only species in Vaccinium section Polycodium (Ashe, 1931; Baker, 1970; Camp, 1945). Endemic in North America, it is found from southwestern Ontario to central Florida and west to eastern Texas, with a few outlying populations in central Mexico (Vander Kloet, 1988). In north Florida, deerberry plants often produce high yields of edible berries while growing on excessively drained, sandy soils in the forest. Cultivated highbush blueberry, which is based on hybrids between Vaccinium corymbosum and other species in Vaccinium section Cyanococcus, has become an important world crop, but deerberry has never been domesticated. There are several reasons for this. Deerberries are large (compared with berries of native plants of other Vaccinium species), juicy, and have high Brix, but the skins and sometimes the flesh have bitter components, ranging from slightly bitter to almost inedibly bitter and astringent depending on the population sampled and the clone sampled within the population. Deerberry seeds are only slightly larger than those of highbush blueberry. The

Received for publication 25 Oct. 2017. Accepted for publication 18 Dec. 2017.

${ }^{1}$ Corresponding author. E-mail: lyrene@ufl.edu.
Deerberries can readily be hybridized in a greenhouse with diploid species in section Cyanococcus, which are close relatives of highbush blueberry (Darrow and Camp, 1945). Most of the hybrids are weak and have very low fertility. We have produced hundreds of seedlings by crossing deerberries with each of three diploid section Cyanococcus species collected from Florida: Vaccinium darrowii, Vaccinium fuscatum, and Vaccinium elliottii. The $\mathrm{F}_{1}$ hybrids varied in vigor depending on the particular clones of each species used as parents, but almost all have been much weaker than typical highbush seedlings.

Deerberries have several characteristics that would be useful in highbush blueberry cultivars. The plants are very drought tolerant and can produce high berry yields when growing in dry forests. The species is polymorphic for berry flesh color. Ripe berries of some deerberry plants have purple or brightred flesh, whereas berries of Vaccinium section Cyanococcus species have green, white, or yellow flesh. Freshly harvested ripe berries from most deerberry clones, when mixed with three volumes of water and crushed by hand to liberate flesh and skin pigments, produce a liquid that is bright red to magenta in color. The same procedure using fresh highbush blueberries normally produces a greenish-brown liquid. Only a few highbush clones produce a pink liquid when their fresh berries are crushed in water.

The corolla tube of deerberry is very short (Fig. 1). Both anthers and stigma project well beyond the end of the tube. This flower structure could make blueberry cultivars easier to pollinate. Carpenter bees (Xylocopa spp.), for example, cut holes in the side of the corolla tube of highbush blueberry and rob nectar without pollinating, but they pollinate deerberry flowers legitimately. Deerberry flowers are "open in the bud" i.e., the stigma is visible in the very small, developing flower long before anthesis (Luteyn et al., 1996).

Deerberry flowers are produced on new spring growth flushes. Deerberry plants produce dimorphic branches: sterile vegetative branches and fertile branches with leafy bracts, which have a flower in the axil of each bract. In some phenotypes, bud size on dormant plants in late winter differs between buds that will give rise to fertile branches and those that will produce purely vegetative branches (anonymous reviewer). In Florida, highbush blueberry plants, which produce their flower buds in the fall, usually have few flowers the following spring if diseases or insects defoliate the plants in August or September. The same is not true of deerberries.

In 2010, we started a program to produce large populations of tetraploid hybrids between highbush blueberry cultivars and tetraploid $V$. stamineum plants obtained by colchicine treatment of seeds and seedlings. The goal was to produce a broad-based hybrid population that could be used to combine horticulturally desirable features of the two taxa and to transfer genetic material 
in either direction from the $F_{1}$ hybrids to the parent species. Production of the first tetraploid hybrids was previously reported, and a description of the fertility and phenotype of the $F_{1}$ hybrids was given (Lyrene, 2016). The purpose of this article is to describe the results of backcrossing these $F_{1}$ intersectional hybrids to the two parent taxa.

\section{Materials and Methods}

Evaluation of hybrid seedlings in highdensity field nursery. Seeds from five types of crosses (Table 1) were produced by hand emasculation and controlled pollination in a greenhouse in Jan. and Feb. 2015 and 2016. The immediate parents of the $F_{1}$ intersectional hybrids used in these crosses included seven advanced tetraploid highbush selections from the University of Florida blueberry breeding program and three tetraploid $V$. stamineum seedlings (Lyrene, 2016). The $V$. stamineum tetraploid parents were obtained using colchicine-treatment of seeds that had been collected from four plants growing on deep, sandy soil in southeastern Alachua County,

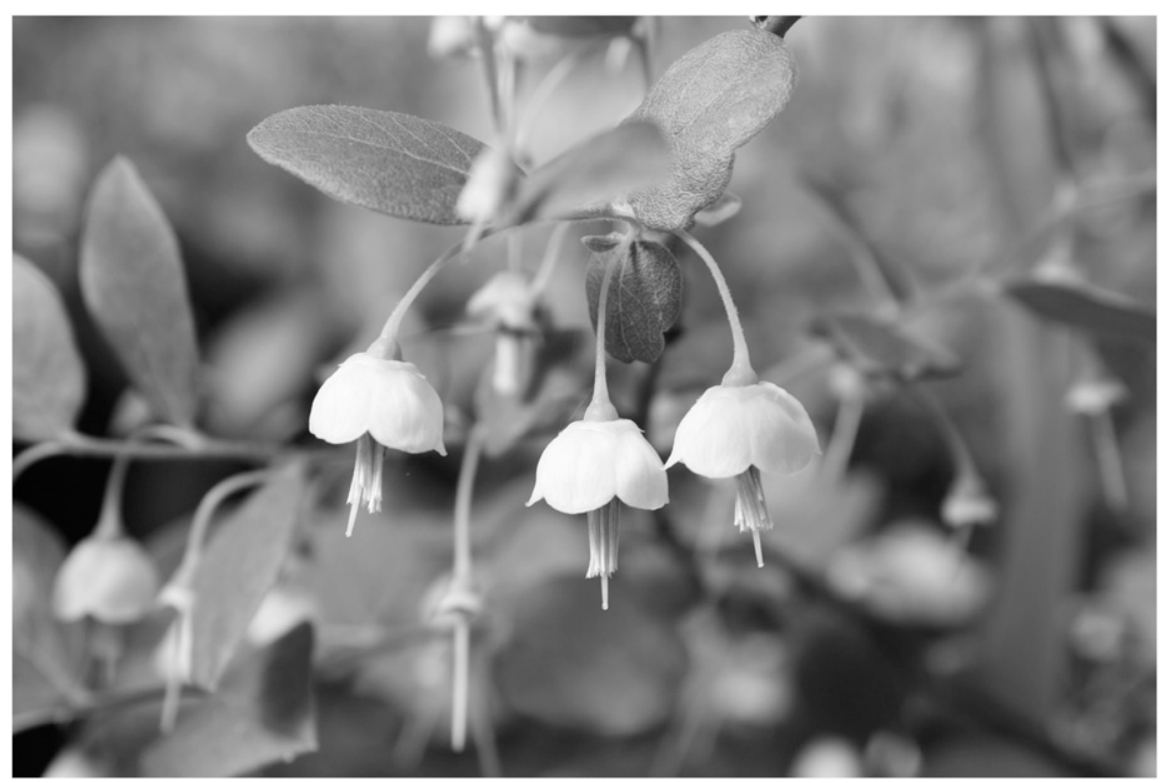

Fig. 1. Flowers of diploid Vaccinium stamineum showing long pedicels and stigma and anthers exserted from the corolla tube.

Table 1. Number of $F_{1}, F_{2}$, and backcross seedlings transplanted to high-density field nurseries in May 2016 and May 2017 from crosses made in 2015 and 2016. ${ }^{\mathrm{z}}$ Seeds were sown in a greenhouse in November of the year the crosses were made and the seedlings were grown in greenhouse trays from January until transplanting.

\begin{tabular}{|c|c|c|c|c|}
\hline \multicolumn{5}{|c|}{ Number of crosses and number of seedlings } \\
\hline \multirow[b]{2}{*}{ Type of $\operatorname{cross}^{y}$} & \multicolumn{2}{|c|}{2016 nursery } & \multicolumn{2}{|c|}{2017 nursery } \\
\hline & Crosses & Seedlings & Crosses & Seedlings \\
\hline$\overline{F_{1}(\mathrm{HB} \times \operatorname{Stam} 4 \mathrm{X})^{\mathrm{x}}}$ & 10 & 350 & 17 & 860 \\
\hline $\mathrm{F}_{2}\left(\mathrm{~F}_{1} \times \mathrm{F}_{1}\right)$ & 6 & 230 & 6 & 600 \\
\hline $\mathrm{BC}_{1}\left(\mathrm{HB} \times \mathrm{F}_{1}\right)$ & 17 & 1,480 & 8 & 640 \\
\hline $\mathrm{BC}_{1}\left(\mathrm{~F}_{1} \times \mathrm{HB}\right)$ & 12 & 1,060 & 19 & 1,440 \\
\hline $\mathrm{BC}_{1}\left(\mathrm{~F}_{1} \times \operatorname{Stam} 4 \mathrm{X}\right)$ & 2 & 48 & 8 & 445 \\
\hline
\end{tabular}

${ }^{\mathrm{z}}$ Most crosses produced far more than 100 seedlings, but no more than 100 random seedlings were saved from each cross.

${ }^{\mathrm{y}}$ Both parents in all crosses were tetraploid and the seedlings are expected to be tetraploid.

${ }^{\mathrm{x}} \mathrm{HB}=$ tetraploid highbush cultivar; Stam $4 \mathrm{X}=$ colchicine-induced tetraploid Vaccinium stamineum. crosses produced fewer than 100 seedlings; others produced far more than the 100 seedlings that were saved. One nursery was planted in May 2016, the other in May 2017. Vigor and growth of plants in each nursery were observed weekly until 1 Nov. 2017.

On 14 Oct. 2016, $149 \mathrm{~d}$ after they had been transplanted to the 2016 high-density field nursery as seedlings $\approx 10 \mathrm{~cm}$ tall, $2536 \mathrm{BC}_{1}$ seedlings were rated for vigor, along with 351 $\mathrm{F}_{1}$ seedlings and 227 seedlings produced by intercrossing $F_{1}$ plants (Table 2). One hundred and eight seedlings from highbush cultivar $\times$ highbush cultivar crosses, and 113 from diploid $V$. stamineum $\times$ diploid $V$. stamineum crosses, which had been transplanted to the same nursery at the same time, were also evaluated. Each seedling was given a vigor score ranging from 1 to 9 . Plants scored in category 1 appeared to be too weak to flower in the following spring. Plants scored 9 were equal in vigor to the most vigorous $8 \%$ of the highbush seedlings. Category 6 comprised plants that had the minimum vigor required in a commercial cultivar.

About $2500 \mathrm{BC}_{1}$ plants remained in the high-density field nursery in Jan. 2017. Several hundred of these plants flowered in January, February, or March and ripened fruit in Apr. and May 2017, $\approx 1.5$ years after the seed was planted to produce them. Many other $\mathrm{BC}_{1}$ plants were too small to flower in 2017. During the ripening season, the plants that had fruit were examined weekly to observe plant and fruit characteristics. Berry size, color, scar, firmness, flavor, flesh color, and cluster looseness were observed for plants that fruited.

Evaluation of the fertility of $B C_{1}$ plants placed in a greenhouse for crossing. On 1 Dec. 2016, from the population of $2536 \mathrm{BC}_{1}$ seedlings growing in the high-density nursery, 35 of the most vigorous plants were dug, potted into $20 \mathrm{~L}$ pots, and placed in a greenhouse for crossing. Three plants were later discarded because they showed no clear indications of being valid hybrids. Fertility of the remaining $\mathrm{BC}_{1}$ seedlings was estimated by examining pollen from each plant and by counting the number of plump seeds produced per pollinated flower after intercrossing $\mathrm{BC}_{1}$ plants. Pollen from the first flowers that opened on each $\mathrm{BC}_{1}$ plant was mounted in $45 \%$ acetic acid on a microscope slide and examined at $250 \times$. Blueberry pollen is shed in tetrads of four microspores. Several hundred pollen tetrads were examined from each plant. Percentage of well-formed microspores was estimated for each $\mathrm{BC}_{1}$ plant. Percentages were based on individual microspores, not on perfectly formed tetrads.

Fertility was also assessed by intercrossing plants during Jan. and Feb. 2017. In each cross, the parents were chosen so that every seedling would have four distinct clones as grandparents. Twenty-six $\mathrm{BC}_{1}$ clones were used as female parents and 13 were used as male parents. Clones were selected as males if they made numerous flowers and shed pollen well. The $\mathrm{BC}_{1}$ plants used as parents had been produced using seven highbush 
Table 2. Number of seedlings from various crosses in each of nine vigor categories, classified $149 \mathrm{~d}$ after the seedlings were transplanted to the 2016 high-density field nursery. Seedlings were transplanted on 18 May and evaluated on 14 Oct. 2016.

\begin{tabular}{|c|c|c|c|c|c|c|c|c|c|c|}
\hline \multicolumn{11}{|c|}{ Vigor categories $^{z}$} \\
\hline & 1 & 2 & 3 & 4 & 5 & 6 & 7 & 8 & 9 & Total type of cross \\
\hline Highbush $\times$ Highbush & 0 & 3 & 19 & 14 & 14 & 11 & 10 & 28 & 9 & 108 \\
\hline Stam $2 X \times \operatorname{Stam} 2 X^{y}$ & 1 & 6 & 10 & 24 & 18 & 15 & 16 & 20 & 3 & 113 \\
\hline $\mathrm{F}_{1}(\mathrm{HB} \times \operatorname{Stam} 4 \mathrm{X})$ & 195 & 82 & 47 & 16 & 4 & 2 & 3 & 2 & 0 & 351 \\
\hline $\mathrm{F}_{2}\left(\mathrm{~F}_{1} \times \mathrm{F}_{1}\right)$ & 102 & 77 & 22 & 18 & 7 & 1 & 0 & 0 & 0 & 227 \\
\hline $\mathrm{BC}_{1}\left(\mathrm{~F}_{1} \times \mathrm{HB}\right)$ & 305 & 280 & 199 & 140 & 37 & 43 & 33 & 17 & 2 & 1,056 \\
\hline $\mathrm{BC}_{1}\left(\mathrm{HB} \times \mathrm{F}_{1}\right)$ & 316 & 458 & 302 & 198 & 97 & 37 & 37 & 34 & 1 & 1,480 \\
\hline $\mathrm{BC}_{1}\left(\mathrm{~F}_{1} \times \operatorname{Stam} 4 \mathrm{X}\right)$ & 23 & 14 & 9 & 2 & 0 & 0 & 0 & 0 & 0 & 48 \\
\hline
\end{tabular}

${ }^{\mathrm{z} C a t e g o r y} 1$ = extremely weak; will probably never flower; Category $6=$ minimum vigor needed in a cultivar; Category $9=$ equal in vigor to the most vigorous $8 \%$ of highbush $\mathrm{x}$ highbush seedlings.

${ }^{\mathrm{y}} \mathrm{Stam} 2 \mathrm{X}=$ diploid Vaccinium stamineum; $\mathrm{Stam} 4 \mathrm{X}=$ tetraploid $V$. stamineum; $\mathrm{HB}=$ highbush cultivar; $\mathrm{F}_{1}=$ Highbush cultivar $\times$ tetraploid $V$. stamineum .

cultivars and nine different $F_{1}$ hybrids, and the $\mathrm{F}_{1}$ parents traced back to three different $V$. stamineum tetraploid plants, FL13-869, FL13-870, and FL13-872 (Lyrene, 2016). Mites (Eotetranychus clitus), which in previous years had been much more damaging on the $F_{1}$ hybrids than on plants of either parent species, were controlled in the greenhouse using predatory mites (Aphidius colemani, Koppert Biological Systems; www. koppert.com).

In making the crosses, flowers were emasculated before anthesis and pollinated immediately using pollen from other plants in the same greenhouse. The number of flowers pollinated and the number of ripe berries harvested from each female parent were recorded. At the end of harvest, the seeds were extracted by manually crushing the berries in $500 \mathrm{~mL}$ of water in a $4 \mathrm{~L}$ plastic bucket, churning the water vigorously by hand, and decanting the skins, pulp, and water. The seeds that remained in the bottom of the bucket were washed several times with a small volume of water, and the clean seeds were poured onto paper towels to dry. The skins, pulp, and water from the first cleaning were saved, and the decanting process was repeated several times until few or no additional good seeds were being recovered. The seeds were dried on a desktop.

The number of plump, well-developed seeds that appeared capable of germinating was estimated for each cross. Where there were fewer than 200 seeds, all were counted. Where there were more than 200 , the total seed mass was spread in an oval on a desktop and visually divided into two equal halves, four equal quarters, or eight equal eighths depending on the seed number. The plump seeds in the smallest division (always 100 or more) were counted and an estimate of the total number of seed was calculated.

Phenotypes of $F_{1}$ and $B C_{1}$ plants and fruit in the greenhouse. During the period of flowering and fruiting, various traits for which highbush and $V$. stamineum differ were examined to see how the $\mathrm{BC}_{1}$ plants compared with the parental taxa and to their $F_{1}$ parents. These traits included presence or absence of pubescence on the leaf petioles and stems of the new shoots, looseness of the flower and berry clusters, position of the tips
$V$. stamineum. The number of plump seeds per pollinated flower was determined.

\section{Results}

Field nursery evaluations of $F_{1}, F_{2}$, and $B C_{1}$ seedling populations. Vigor of $\mathrm{BC}_{1}$ seedlings on 14 Oct. 2016, after $149 \mathrm{~d}$ in the 2016 high-density field nursery (Table 2), averaged far lower (median vigor score 2) than highbush seedlings (median score between 5 and 6) and $V$. stamineum seedlings (median 5) in the same nursery. $\mathrm{BC}_{1}$ seedling vigor was highly variable; 114 of the 2536 $\mathrm{BC}_{1}$ seedlings received vigor scores of 7,8 , or 9. Plant vigor varied greatly depending both on the particular clones used in the backcross and on the seedling within the segregating population of each cross. Some crosses produced only weak $\mathrm{BC}_{1}$ seedlings. From other crosses, some $\mathrm{BC}_{1}$ seedlings were vigorous enough to be successful cultivars. The $\mathrm{BC}_{1}$ seedlings averaged higher in vigor than the $351 \mathrm{~F}_{1}$ seedlings and the $227 \mathrm{~F}_{2}$ seedlings, both of which had median vigor scores of 1 (Table 2). $F_{2}$ seedlings seemed no more vigorous and no more variable in vigor than $F_{1}$ seedlings, even though the $F_{2}$ plants were obtained by intercrossing unrelated $F_{1}$ plants. In both $F_{1}$ and $F_{2}$, leaf color of many plants were bronze, rather than green. Most $F_{1}$ plants in the 2014 and 2015 nurseries had this same leaf color (Lyrene, 2016). Some $\mathrm{BC}_{1}$ plants also had bronze-colored leaves, but most had green leaves.

By Aug. 2017, 10 months after the original assessment, both average vigor and variability in vigor among plants within the $\mathrm{F}_{2}$ and $\mathrm{BC}_{1}$ crosses had greatly increased in the 2016 field nursery. When the most vigorous $\mathrm{F}_{1}$ and $\mathrm{BC}_{1}$ plants were potted in peat and irrigated with water from which most bicarbonates had been removed or were transplanted to rows irrigated using drip tubes with acidified water, many of the hybrid seedlings became highly vigorous, with excellent leaf color.

Only $\approx 20 \%$ of the $\mathrm{BC}_{1}$ seedlings in the high-density nursery flowered and produced fruit after 1 year in the field, compared with $60 \%$ to $80 \%$ of the highbush seedlings in the same nursery. Many $\mathrm{BC}_{1}$ plants that were too small to flower in 2017 will probably flower in 2018. Most $\mathrm{BC}_{1}$ plants in the field flowered later in the season than highbush seedlings in the same nursery, and the mean date of $50 \%$ ripe berries for the $\mathrm{BC}_{1}$ population was $\approx 1$ month later than for the highbush seedlings. Although there was much variation in flowering and ripening time among the $\mathrm{BC}_{1}$ seedlings, none flowered or ripened earlier than seedlings from highbush cultivars such as 'Jewel', 'Emerald', and 'Farthing'.

Most $\mathrm{BC}_{1}$ plants in the field nursery had high berry set after open pollination, although one cross produced many seedlings that set fruit poorly and others had one or more seedlings that flowered but set little fruit. Compared with the berries from highbush $x$ highbush crosses in the same nursery, berries 

smaller, darker, and lower in sugar and acid, but seedlings were highly variable, both within and between crosses. Frequency of plants with excessive berry stemminess or berry shattering was higher among $\mathrm{BC}_{1}$ these problems. Only a small fraction of the $\mathrm{BC}_{1}$ plants produced berries having exotic flavors not expected in highbush seedlings. A small fraction of the $\mathrm{BC}_{1}$ plants produced some berries having traces of pink in the flesh, but most plants produced berries with white to greenish-yellow flesh similar to highbush. Most $\mathrm{BC}_{1}$ plants had flowering racemes with unusually long peduncles and pedicels and berry clusters that were unusually loose.

Fertility of $F_{1}$ and $B C_{1}$ plants in the greenhouse. When the 35 vigorous $\mathrm{BC}_{1}$ plants that had been moved to the greenhouse for use as parents in 2017 began to flower, several were discarded because they lacked clear signs of $V$. stamineum introgression (flowers resembled highbush flowers, lack of pubescence on leaf petioles and new growth flushes, and highbush-like leaf color and venation).

The $33 \mathrm{BC}_{1}$ seedlings whose pollen was examined had much higher percent good pollen than the $34 \mathrm{~F}_{1}$ plants examined (Table 3 ). The median percent good pollen for the $\mathrm{BC}_{1}$ seedlings was $\approx 60 \%$, and 11 of the plants had percent well-formed pollen similar to what is seen in highbush cultivars. No $\mathrm{BC}_{1}$ plants appeared to have less than $10 \%$ good pollen. Pollen was examined for only five $\mathrm{BC}_{1}$ plants in which tetraploid $V$. stamineum had been the recurrent parent. on $\mathrm{BC}_{1}$ plants in the field nursery averaged populations, but most plants were free of

These plants averaged somewhat lower in percent good pollen than seedlings from the backcrosses to highbush, but the $V$. stamineum $\mathrm{BC}_{1}$ plants were barely large enough to flower, and the results were not considered conclusive.

In the greenhouse crosses of 2017 (Table 4), the $26 \mathrm{BC}_{1} \times \mathrm{BC}_{1}$ crosses produced an average of 9.29 plump seeds per pollinated flower, which was higher than the highbush $\times$ $F_{1}$ and $F_{1} \times$ highbush crosses, but lower than the $15-30$ seeds per pollinated flower that would be expected from highbush $\times$ highbush crosses (Lyrene, 1989). Success rates from similar crosses made in 2015 and 2017 differed considerably, (compare Table 4 with Lyrene, 2016), but seed set from all crosses was high enough to allow the highbush and $V$. stamineum gene pools to be combined with little difficulty.

Phenotypes of $F_{I}$ and $B C_{I}$ plants in the greenhouse. The plants placed in the greenhouse received little or no chilling before or after they were dug. Most of the plants still had some old leaves from the previous season's growth when they were dug, but most old leaves abscised within 2 months after the plants were placed in the greenhouse. Because of the lack of chilling, flushing of new leaves was slow on some plants. The first flowers opened in late Dec. 2016, and flowering continued through the end of Feb. 2017. Most flower buds on most plants opened and produced flowers, but the flowering period was very long, probably due in part to the lack of chilling.

In highbush blueberry flowers, the stigma is normally located near the tip of the corolla tube and the anthers are located well inside

Table 3. Number of plants with percent well-formed pollen grains in three hybrid populations.

\begin{tabular}{lccc}
\hline Percent good microspores & $\mathrm{F}_{1}$ Seedlings $^{\mathrm{z}}$ & $\mathrm{BC}_{1}$ to Highbush & $\mathrm{BC}_{1}$ to Stamineum $^{\mathrm{y}}$ \\
\hline $0-9$ & 2 & 0 & 0 \\
$10-19$ & 6 & 3 & 1 \\
$20-29$ & 9 & 2 & 1 \\
$30-39$ & 6 & 2 & 0 \\
$40-49$ & 3 & 3 & 2 \\
$55-59$ & 5 & 6 & 0 \\
$60-69$ & 1 & 2 & 1 \\
$70-79$ & 0 & 0 & 0 \\
$80-89$ & 0 & 4 & 0 \\
$90-100$ & 2 & 11 & 0 \\
Median score & 30 & 60 & 45 \\
Mean & 30.9 & 62.7 & 38.0 \\
Standard deviation & 21.97 & 30.29 & 18.60
\end{tabular}

Backcross $_{1}=\mathrm{BC}_{1}$.

${ }^{\mathrm{z}} \mathrm{F}_{1}=$ Highbush cultivar $\times$ tetraploid Vaccinium stamineum.

${ }^{\mathrm{y}}$ Tetraploid plant produced by colchicine treatment. the corolla tube. In $V$. stamineum, the tips of the anther tubes extend well beyond the tip of the corolla tube, and the style and stigma extend well beyond the anther tubes (Fig. 1). The positions of the anthers and stigmas relative to the tip of the corolla tube in $F_{1}$ hybrids was intermediate between the highbush and $V$. stamineum parents, and the $\mathrm{BC}_{1}$ plants were intermediate between highbush and the $F_{1}$ (Table 5; Fig. 2). Both the $F_{1}$ and $\mathrm{BC}_{1}$ populations were quite variable in this character. Among the $31 \mathrm{BC}_{1}$ plants measured, four had stigmas that were $1 \mathrm{~mm}$ inside the corolla tube and two had stigmas $2 \mathrm{~mm}$ outside the corolla tube. One $\mathrm{BC}_{1}$ plant had the tips of the anther tubules $3 \mathrm{~mm}$ inside the corolla tube and four had anther tubules even with the tip of the corolla tube.

Flowers of $V$. stamineum have anther awns, prominent curved appendages attached to the pollen sac, whereas the flowers of section Cyanococcus lack these awns. Anther awns were present in all but a few $\mathrm{BC}_{1}$ plants, but were much smaller than in $V$. stamineum. A few $\mathrm{BC}_{1}$ plants that lacked anther awns had flowers conspicuously open in the bud and pubescent stems and petioles, all of which are $V$. stamineum characters. Petiole pubescence was present in all $\mathrm{BC}_{1}$ plants and absent from the highbush cultivars.

The $25 \mathrm{BC}_{1}$ plants for which berry weight was determined based on berries harvested from the greenhouse after hand pollination averaged $1.68 \mathrm{~g}$ per berry, compared with a mean of $2.20 \mathrm{~g}$ for the seven highbush cultivars with which they were compared (Table 6). The $10 \mathrm{~F}_{1}$ plants sampled averaged $1.13 \mathrm{~g} /$ berry. Average weight of berries harvested from the forest from five V. stamineum plants that had been selected for large fruit was $1.00 \mathrm{~g}$. Berries weighed from these five plants were selected randomly, not because they were the largest.

Skin color of ripe berries on most of the 26 hand-pollinated $\mathrm{BC}_{1}$ plants was shiny black, but berries on several plants had a mediumheavy waxy bloom, similar to that of highbush blueberry cultivars. When polished, the berries on all plants had dark black skins, indicating normal anthocyanin development. None of the $\mathrm{BC}_{1}$ plants from the greenhouse showed more than a slight hint of pink in the flesh of the ripe berries, even though one of the grandparent $V$. stamineum plants and several of the parental $F_{1}$ hybrids had red to purple flesh. When the ripe berries were submerged in three volumes of water and smashed by hand to remove the seeds, the

Table 4. Results of crosses made in the greenhouse in 2017.

\begin{tabular}{|c|c|c|c|c|}
\hline Type of cross $^{z}$ & Number of crosses & Total flowers pollinated & Plump seeds total number & Plump seeds per flower pollinated \\
\hline$\overline{\mathrm{BC}_{1} \times \mathrm{BC}_{1}}$ & 26 & 3,410 & 31,672 & 9.29 \\
\hline $\mathrm{HB} \times \mathrm{Stam} 4 \mathrm{X}$ & 7 & 1,415 & 3,093 & 2.19 \\
\hline $\mathrm{HB} \times \mathrm{F}_{1}$ & 3 & 428 & 2,770 & 6.47 \\
\hline $\mathrm{F}_{1} \times \mathrm{HB}$ & 8 & 1,111 & 5,120 & 4.61 \\
\hline $\mathrm{F}_{1} \times \mathrm{F}_{1}$ & 4 & 715 & 131 & 0.18 \\
\hline $\mathrm{F}_{1} \times \operatorname{Stam} 4 \mathrm{X}$ & 6 & 1,184 & 2,678 & 2.26 \\
\hline Myrsinites $\times$ Stam $4 \mathrm{X}$ & 4 & 1,076 & 134 & 0.12 \\
\hline
\end{tabular}

${ }^{\mathrm{z} \mathrm{BC}_{1}}=$ (highbush cultivar $\times$ tetraploid Vaccinium stamineum $) \times$ highbush cultivar; $\mathrm{HB}=$ highbush cultivar; Stam $4 \mathrm{X}=$ any one of three tetraploid $V$. stamineum plants; $\mathrm{F}_{1}=$ highbush cultivar $\times$ tetraploid V. stamineum; Myrsinites $=$ any one of four clones of the Florida tetraploid, lowbush species, Vaccinium myrsinites. 
Table 5. Positions of the stigma and distil end of the anther tubules relative to the distil end of the corolla tube for highbush cultivars, tetraploid Vaccinium stamineum, $\mathrm{F}_{1}$ hybrids, and $\mathrm{BC}_{1}$ hybrids. Negative values indicate that the stigma or anthers are inside the corolla tube and positive values indicate they are exserted. Values are distances in $\mathrm{mm} .^{\mathrm{z}}$

\begin{tabular}{lccc}
\hline & Genotypes measured (no.) & Mean location of stigma & Mean location of anthers \\
\hline $\mathrm{HB}^{\mathrm{y}}$ & 15 & -0.13 & -3.33 \\
$\mathrm{BC}_{1}$ & 31 & 0.42 & -1.32 \\
$\mathrm{~F}_{1}$ & 18 & 2.35 & 0.11 \\
Stam $4 \mathrm{X}$ & 4 & 10.00 & 6.00 \\
\hline
\end{tabular}

${ }^{\mathrm{z}}$ Within columns, each pair of means differs at $P=0.00001$ by Students $t$ test, except for mean positions of stigma for $\mathrm{BC}_{1}$ and highbush, which differ at $P=0.025$.

${ }^{\mathrm{y}} \mathrm{HB}=$ highbush cultivars; $\mathrm{BC}_{1}=$ highbush cultivar $\times \mathrm{F}_{1}$ or the reciprocal; $\mathrm{F}_{1}=$ highbush cultivar $\times$ tetraploid $V$. stamineum; Stam $4 \mathrm{X}=$ tetraploid $V$. stamineum.

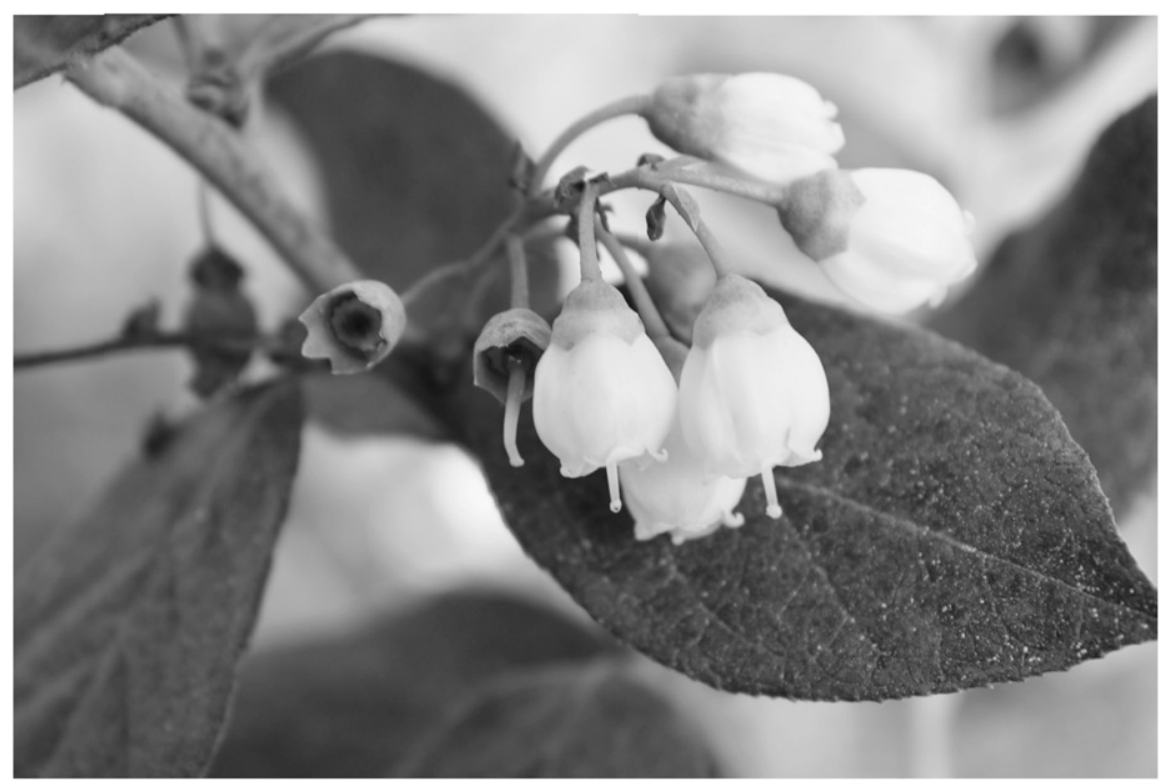

Fig. 2. Flowers and leaf of one $\mathrm{BC}_{1}$ hybrid (highbush $\times$ Vaccinium stamineum) $\times$ highbush showing exserted style.

Table 6. Weight of berries following hand-pollination in the greenhouse for highbush cultivars, $\mathrm{F}_{1}$ hybrid seedlings (highbush cultivar $\times$ tetraploid Vaccinium stamineum), $\mathrm{BC}_{1}$ seedlings $\left(\mathrm{F}_{1} \times\right.$ highbush), and for berries harvested from the forest from five heavily laden diploid $V$. stamineum plants that had been selected for high yield and large berries.

\begin{tabular}{lcccc}
\hline & Highbush cultivars & $\mathrm{F}_{1}$ seedlings & $\mathrm{BC}_{1}$ seedlings & V. stamineum from forest \\
\hline Number of plants sampled & 5 & 10 & 25 & 5 \\
Berries weighed per plant & 15 & 15 & 15 & 200 \\
Mean berry weight $(\mathrm{g})$ & $2.20 \mathrm{a}^{\mathrm{x}}$ & $1.13 \mathrm{c}^{\mathrm{x}}$ & $1.68 \mathrm{~b}^{\mathrm{x}}$ & 1.00 \\
Standard deviation & 0.450 & 0.341 & 0.422 & 0.089 \\
Standard error of mean & 0.170 & 0.108 & 0.084 & 0.040 \\
\hline
\end{tabular}

Backcross $_{1}=\mathrm{BC}_{1}$.

${ }^{\mathrm{z}}$ Diploid. All other populations are tetraploid.

${ }^{\mathrm{y}}$ Each plant was a different genotype.

${ }^{\mathrm{x}}$ These three means differ at $P=0.05$ according to pairwise $t$ tests.

color of the water/juice mixture varied greatly among $\mathrm{BC}_{1}$ plants. In some, the liquid was dark red to purple, in others pink to red, and in a few, brown to yellow. When highbush blueberries received the same treatment, a few clones gave a pink to light rose-colored liquid, but most produced a liquid that was green to yellow to brown.

The tendency of ripe berries to fall easily from the plant (shatter) with the pedicel attached to the berry varied greatly among the $\mathrm{BC}_{1}$ plants. In $\approx 20 \%$ of the genotypes, shattering was higher than what would be acceptable in a cultivar. On many $\mathrm{BC}_{1}$ the same for the $\mathrm{BC}_{1}$ as for the berries of highbush blueberry seedlings.

A few ripe berries were tasted from each $\mathrm{BC}_{1}$ plant that was used as a female parent. Bitterness, a characteristic of $V$. stamineum berries, was not detected in either the skin or flesh of more than half of the $\mathrm{BC}_{1}$ plants. Bitterness was high enough to be objectionable in the berries of only three or four $\mathrm{BC}_{1}$ plants in the greenhouse, and even these berries were far less bitter than typical craft beers or red wines. Berry acidity, as judged by tasting the berries, varied from high to low among the $\mathrm{BC}_{1}$ clones, but on average was lower than in highbush berries. Many of the berries sampled did not seem very sweet. Of the $34 \mathrm{BC}_{1}$ plants evaluated in the greenhouse, 18 had no detectable aromatic flavor components, 14 had detectable but not high levels, and two were rated as highly aromatic.

A desirable feature of $V$ stamineum is the very open flower cluster, resulting from inflorescences in which the pedicels and peduncles of the flowering raceme are much longer than those of species in section $\mathrm{Cya}$ nococcus. Long pedicels and peduncles are desirable because the great increase in berry size that has accompanied domestication of the highbush blueberry has resulted in berries that are pressed together in the clusters of some cultivars. Loose clusters make berries easier to harvest mechanically. "Cluster looseness" was rated for the $\mathrm{BC}_{1}$ plants and, with few exceptions, was rated high or very high compared with cultivars such as 'Emerald', 'Jewel', and 'Farthing' (Fig. 3).

Results of pollinating $B C_{1}$ [(highbush $\times$ $V$. stamineum) $\times V$. stamineum] plants with pollen from tetraploid $V$. stamineum. Three of the five small $\mathrm{BC}_{1}$ seedlings in which tetraploid $V$. stamineum was the recurrent parent produced a few flowers in the greenhouse, and 12 plump seeds resulted when these were pollinated with pollen from tetraploid $V$. stamineum to produce $\mathrm{BC}_{2}$ seed. A larger population of $\mathrm{BC}_{1}$ seedlings of this type will be available for crosses in 2018 (Table 1).

Results of $V$. myrsinites $\times$ tetraploid $V$. stamineum crosses. The 1076 emasculated flowers of $V$. myrsinites that received pollen from tetraploid $V$. stamineum gave only 134 plump seeds, a success rate far lower than from the highbush $\times$ tetraploid $V$ stamineum crosses. Because both highbush cultivars and $V$. myrsinites are tetraploids in section $\mathrm{Cya}$ nococcus, the differing results when the two were crossed with tetraploid $V$. stamineum were unexpected. Seedlings from the $V$. myrsinites crosses will be grown to determine whether they are the intended hybrids and whether they are vigorous enough to flower.

\section{Discussion}

Caution needed in selecting parents for backcrosses. Putative $\mathrm{F}_{1}$ seedling populations from some of the highbush $\times$ tetraploid $V$. stamineum crosses made during the past 5 years have contained some plants that were clearly not the intended hybrids. These plants 


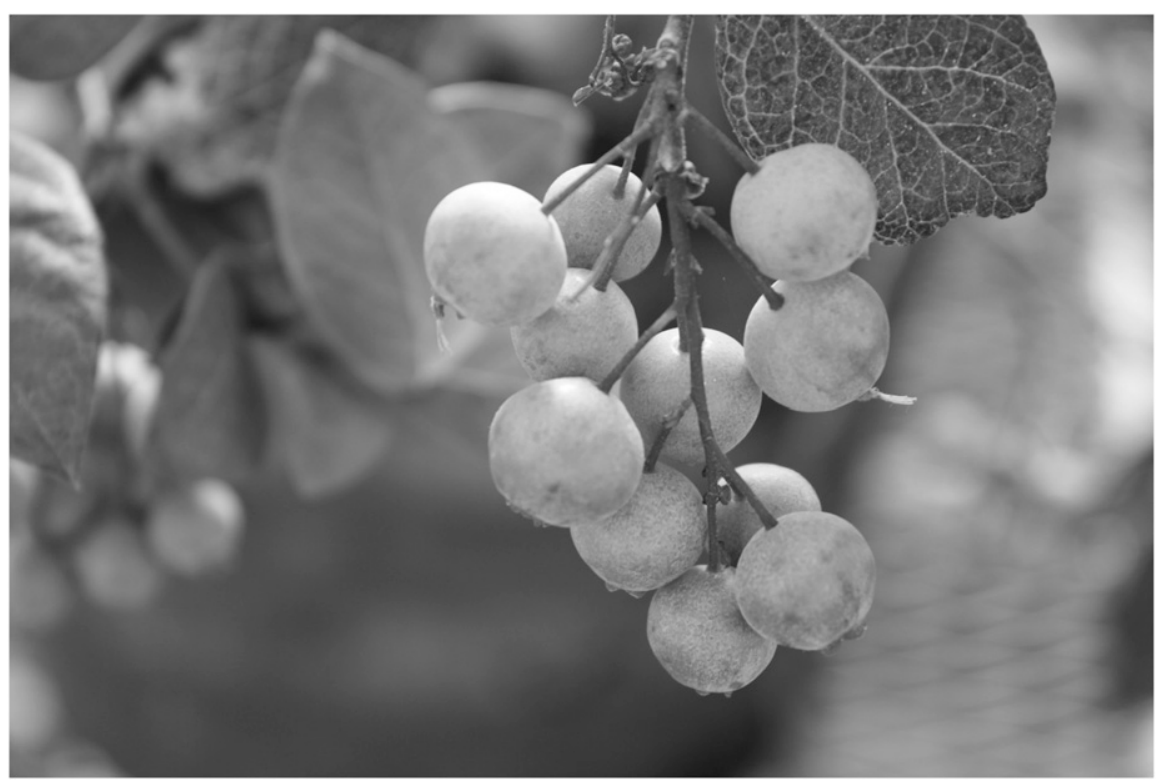

Fig. 3. Immature berries from a $\mathrm{BC}_{1}$ hybrid showing long pedicels and peduncle.

were more vigorous than the intersectional hybrids and had no obvious $V$. stamineum characteristics. Most resembled highbush $\times$ highbush seedlings. They were not used in data sets or in crosses. Seedling populations from difficult crosses, in which hundreds of flowers must be pollinated to produce a few hybrids, often contain a few plants from selfpollination, pollination from other unintended sources, or from seeds splashed from one pot to another. A few extremely vigorous seedlings have appeared in our $\mathrm{F}_{1}$ highbush $\times$ tetraploid $V$. stamineum populations that were neither typical $F_{1}$ hybrids nor typical highbush seedlings. These were interesting because of their high vigor and unusual phenotypes, but were not studied further.

Phenotypes of hybrid plants: vigor. Vigor of $\mathrm{F}_{1}$ and $\mathrm{BC}_{1}$ seedlings resulting from hybridization between Vaccinium section Cyanococcus species and Florida V. stamineum depended greatly on the particular clones chosen as parents. This was true of diploid seedlings from crosses between diploid V. stamineum and diploid Cyanococcus species ( $V$. darrowii, $V$. elliottii, and $V$. fuscatum) and in the tetraploid intersectional crosses and backcrosses reported here. Some hybrid populations have been extremely weak. Some tetraploid crosses produced many seedlings with vigor approaching that of highbush cultivars. Because the tetraploid $\mathrm{F}_{1}$ hybrids that were used to make backcrosses were extremely variable, it was not surprising that vigor varied greatly among $\mathrm{BC}_{1}$ seedling populations derived from different $\mathrm{F}_{1}$ plants. It was more surprising to find that crosses involving the diploid species gave seedling populations ranging from barely viable to medium vigorous, depending on the particular plants chosen to make the crosses.

Flowers and flowering. Vaccinium stamineum plants of the type used in these crosses are prolific flower producers, in the forest, in field nurseries, and as potted plants. Many of the $\mathrm{BC}_{1}$ plants placed in the greenhouse produced large numbers of flowers for plants of their size and age. The most vigorous $\mathrm{BC}_{1}$ plants in the field nursery also flowered prolifically.

The flowers of Vaccinium section Cyanococcus species are pollinated in the forest by sonicating bees (Cane et al., 1985). The anthers are located well inside the corolla extends to the outer edge of the corolla tube, nectar, and pollen are not readily available to visiting honeybees. Large blueberry plantations in Florida and Georgia often have reduced fruit set because honeybees placed in the fields to pollinate blueberries abandon the fields to work in flowers of native plants such as red maple (Acer rubrum) and titi (Cyrilla racemiflora) in the surrounding forests and swamps. The problem is exacerbated when carpenter bees (Xylocopa sp.) cut slits at the base of the corolla tube, after which honeybees rob nectar from slits rather than visiting the corolla aperture. Both the stigmas and the anthers of $V$. stamineum are exserted well beyond the end of the corolla tube and offer much easier access to a variety of potential pollinators. $\mathrm{F}_{1}$ and $\mathrm{BC}_{1}$ populations were highly variable in flower structure. In general, $\mathrm{F}_{1}$ plants had flowers intermediate between the two parents. $\mathrm{BC}_{1}$ populations remained highly variable with respect to the relative positions of the stigma, the anthers, and the end of the corolla tube, indicating that it should be rather easy to select for flowers that give easier access to honeybees and other pollinating insects.

Fertility of hybrids. It is not clear why tetraploid hybrids between highbush cultivars and tetraploid $V$. stamineum were so much more fertile than diploid hybrids between diploid $V$. stamineum and diploid section Cyanococcus species, such as $V$. darrowii, V. elliottiii, and V. fuscatum. Genetic redundancy provided by tetraploidy tube, and even though the stigma normally may circumvent problems that make the diploids sterile. Tetraploid intersectional $F_{1}$ hybrids are expected to have two complete sets of chromosomes from each section, which may allow regular chromosome pairing and distribution during meiosis. However, if amphidiploid chromosome pairing explains the increased fertility of the tetraploid $\mathrm{F}_{1}$ hybrids compared with diploid hybrids, it is surprising that the $\mathrm{BC}_{1}$ generation is much more fertile than the tetraploid $\mathrm{F}_{1}$ hybrids. $\mathrm{BC}_{1}$ plants would be expected to have three sets of chromosomes from section Cyanococcus and one set from $V$. stamineum, which should cause meiotic irregularities if highbush chromosomes pair poorly with $V$. stamineum chromosomes. It is possible that selection against dysfunctional gametes and zygotes when the $F_{1}$ hybrids were backcrossed to highbush resulted in $\mathrm{BC}_{1}$ populations that had been strongly selected for compatible gene combinations.

Berry characteristics. The late ripening of $\mathrm{BC}_{1}$ seedlings in the field nursery compared with highbush seedlings was not surprising. $V$. stamineum ripens in north Florida during July, whereas southern highbush cultivars ripen from mid-April to mid-May.

The berries of Vaccinium stamineum parent FL13-872 had purple flesh, and in most $F_{1}$ hybrids obtained by crossing it with highbush cultivars, flesh color ranged from pink to purple (Lyrene, 2016). Berry flesh in almost all $\mathrm{BC}_{1}$ plants, both in the field and in the greenhouse, was white, with tints of yellow, green, or brown, which is typical of highbush berries. When fully ripe, berries of a few $\mathrm{BC}_{1}$ seedlings had pink-white to pink flesh. A few very-mature highbush berries from the same nursery had pink streaks in the flesh, but pink flesh was much more common and more strongly expressed in $\mathrm{BC}_{1}$ seedlings. It is hoped that the $\mathrm{BC}_{1} \times \mathrm{BC}_{1}$ crosses will produce some seedlings with red pigments in the flesh.

Many $\mathrm{BC}_{1}$ seedlings from the greenhouse produced bright red juice/water mixes when fresh, undamaged berries were smashed in water to remove the seeds $(\approx 3$ volumes of water per 1 volume of berries). Most highbush clones produce a brown-to-green water/ juice mix with similar treatment. A few highbush clones give a pink-to-red water/ juice mix, but none of the hundreds tested in this study produce the deep red obtained from most $\mathrm{BC}_{1}$ seedlings. Purees made with a food blender from fresh $\mathrm{BC}_{1}$ berries would be visually much more attractive than those made from fresh highbush blueberries. The berries of $\mathrm{BC}_{1}$ seedlings either had more red pigments in the skin than highbush berries, or their pigments were more readily released when the fresh, undamaged berries were crushed. After highbush blueberries are cooked or frozen, dark purple pigments that are released from the skin make brightly colored jellies and pies.

The most problematic aspect of berry flavor among the $\mathrm{BC}_{1}$ clones was low sugar. Low sugar may have been due in part to the fact that the plants in the greenhouse had 
limited foliage while the berries were developing and maturing. The plants had not been chilled before the crosses were made, and the berries tended to develop faster than the new leaves. The old leaves had mostly abscised or were senescent by the time the berries were ripe. Berry sweetness improved in the last-harvested berries as the new leaves matured. Many of the $\mathrm{BC}_{1}$ plants in the high-density field nursery also seemed low in sugar compared with highbush seedlings in the same nursery. Some $\mathrm{BC}_{1}$ seedlings, both in the greenhouse and in the field, had berries that tasted as good as those of blueberry cultivars such as Emerald, Jewel, and Farthing.

Pleasant tertiary flavor components (in addition to sugar and acid) are conspicuous in the berries of some highbush blueberry cultivars when these are grown in environments that favor complex flavor development. In the $V$. stamineum populations from which our parent plants came, the berries, despite some bitterness, have a unique flavor component that most people consider pleasant, or at least interesting. Failure to find $\mathrm{BC}_{1}$ seedlings in either the greenhouse or the field whose berries had intense, pleasant flavors not found in highbush blueberry was disappointing. Some plants gave hints of exotic flavors, and these flavors could probably be intensified by recurrent selection. Bitter flavors, which can be objectionable in $V$. stamineum, were absent or greatly reduced in $\mathrm{BC}_{1}$ berries.

Outlook for moving useful characteristics from $V$. stamineum into highbush-type cultivars. Hybridization with $V$. stamineum could increase drought tolerance and upland adaptation in blueberry cultivars. Highbush blueberry is a "swamp" species. In the wild, it is normally found on well-drained, acid soils that are high in organic matter and have a dependable moisture supply. In the southeastern United States, V. stamineum thrives on excessively drained, coarse, white sand, in forested communities of drought-tolerant plant species. The basis for drought tolerance in $V$. stamineum has not been studied. Threeyear-old plants dug from our high-density field nurseries do not have large, deep roots as $V$. arboreum plants dug from the same nursery. Drought tolerance could be a major benefit from introgression of $V$. stamineum genes, but we have not grown $\mathrm{BC}_{1}$ seedlings in an environment that would test drought tolerance.

Obtaining commercial cultivars following hybridization of highbush cultivars with $V$. stamineum will require that most of the desirable features of the highbush cultivars be quickly recovered by backcrossing, whereas selected useful traits from $V$. stamineum are retained. $\mathrm{BC}_{1}$ populations showed rapid progress back toward a highbush phenotype. In both field and greenhouse (Table 6), berries on $\mathrm{BC}_{1}$ plants averaged only slightly smaller than berries from highbush seedlings and cultivars. Plant architecture of most hybrids was similar to that of highbush cultivars. Berry color, scar, freedom from attached stems, and flavor were highly variable in $\mathrm{BC}_{1}$ populations, and some seedlings were near cultivar standards in all respects.

Allard (1960) and Stebbins (1950) hypothesized that characteristics of the recurrent parent are rapidly recovered in backcrosses involving wide hybrids because gametic and zygotic selection in partially fertile wide hybrids favors gametes and zygotes that most resemble those of the parent species, in which harmonious gene combinations have been selected over countless generations.

In the field nursery, highbush $\times$ tetraploid $V$. stamineum $\mathrm{F}_{1}$ hybrids were clearly distinct from highbush seedlings, even before they flowered. In the $\mathrm{BC}_{1}$ populations, most seedlings were clearly different from highbush, but a few would not have been conspicuous had they been mixed with seedlings from highbush crosses. Only the combination of flower, fruit, leaf, and stem characteristics showed that these plants were valid $\mathrm{BC}_{1}$ hybrids. One additional backcross to highbush cultivars would probably produce many seedlings that could scarcely be distinguished by phenotype from seedlings having no Polycodium genes. Because a breeder would be selecting for berry and plant characteristics desired in cultivars, most of which resemble the highbush phenotype, the return to highbush-like plants would be fast. Undoubtedly, many $V$. stamineum chromosome segments would persist in the $\mathrm{BC}_{2}$ seedlings that most resembled highbush cultivars. These introgressed genes from $V$. stamineum would give a richer, more-variable gene pool, and could lead to interesting phenotypes when $\mathrm{BC}_{1}$ or $\mathrm{BC}_{2}$ seedlings are intercrossed.

Prospects for domesticating the deerberry. The ability of deerberry to produce high yields of large berries while growing on droughty soils has been noted (Ballington et al., 1984; Ballington, 1995). Deerberries are extremely variable, both within locations and between locations, and genes are probably available within the species for solving the major problems that have so far prevented its domestication. These include difficult vegetative propagation, bitter or astringent flavor components, and the tendency for ripe berries to shatter from the bush. Both shattering and berry bitterness vary greatly among plants in wild populations of $V$. stamineum. If time and effort equal to what was spent domesticating the highbush blueberry were devoted to $V$. stamineum, deerberry could probably become an important new crop.

Whether introgressing genes from highbush cultivars would be necessary, or even useful, in domesticating the deerberry, is uncertain. Essential traits such as nonshattering berries, easy vegetative propagation by stem cuttings, and freedom from bitter flavor components are almost universal in highbush blueberries. The fact that highbush blueberries are tetraploid and the great genetic diversity in $V$. stamineum is at the diploid level complicates the use of highbush cultivars in the domestication of the deerberry.
There is no easy way to move genes from the tetraploid to the diploid level, and a breeder would not want to breed deerberries at the tetraploid level if only a small amount of $V$. stamineum diversity could be made tetraploid. Breeding tetraploid deerberry cultivars while avoiding a genetic bottleneck by using a large number of tetraploid $V$. stamineum plants in the foundation crosses might be the best approach.

Phylogenetic distances separating Vaccinium sections Cyanococcus (highbush blueberry), Polycodium (V. stamineum), and Batodendron ( $V$. arboreum). These are the three Vaccinium sections represented by species native in Florida. Little is known about when, where, and how the three sections originated, diverged genetically, and became widely established in Florida. Which is more closely related to highbush blueberry: $V$. stamineum or $V$. arboreum? Evidence from berry anthocyanins suggests that $V$. arboreum is closer (Ballinger et al., 1982). The anthocyanins in sparkleberry are similar to those in blueberry, whereas those in deerberry resemble those in cranberry (Vaccinium macrocarpon, section Oxycoccus; Ballinger et al., 1982).

Darwin (1859) listed three ways to estimate the phylogenetic distance between two taxa using crossing experiments: how easy is it to make the cross?; how vigorous or weak are the hybrids?; and how fertile are the hybrids when intercrossed or backcrossed to the parent species? Darwin wrote before chromosomes and polyploidy were discovered and before the triploid block was recognized. His method of estimating genetic distance based on the ease of hybridizing taxa works in Vaccinium only with homoploid crosses because the triploid block imposes a superficial secondary barrier to hybridization that is not directly related to genetic consanguinity.

Diploid species in section Cyanococcus, such as $V$. darrowii, V. elliottii, and diploid $V$. fuscatum, can readily be crossed as female parent with both $V$. stamineum and $V$. arboreum, producing hundreds if not thousands of seedlings (P.M. Lyrene, unpublished data). $V$. stamineum and $V$. arboreum seem to differ little in the ease with which such diploid hybrids can be obtained. Despite substantial attempts during several crossing seasons, hybrids using diploid Cyanococcus species as the pollen parent and $V$. stamineum or $V$. arboreum as the seed parent have not been obtained.

Highbush cultivars have been easier to cross with tetraploid $V$. stamineum than with tetraploid $V$. arboreum. In part, this is because tetraploid $V$. stamineum flowers shed much more pollen than tetraploid $V$. arboreum flowers under our greenhouse conditions. With patience, large numbers of tetraploid hybrids can be obtained from both types of crosses if fertile tetraploid plants of $V$. arboreum and $V$. stamineum are available.

At both the diploid and tetraploid level, hybrids between Cyanococcus species and $V$. arboreum have been more vigorous than 
hybrids between the same Cyanococcus species and $V$. stamineum. The most vigorous $\mathrm{F}_{1}$ hybrids from $V$. darrowii $\times V$. arboreum and from diploid $V$. fuscatum $\times V$. arboreum were easy to maintain in field plantings, and some plants began heavy annual flowering after several years in the field. By contrast, most diploid hybrids between section Cyanococcus species and $V$. stamineum have died before flowering. Tetraploid interspecific hybrids have been stronger than the diploids, but highbush hybrids with $V$. stamineum have still been weaker than those with $V$. arboreum.

With respect to fertility of $\mathrm{F}_{1}$ hybrids, $V$. arboreum and $V$. stamineum crosses differed little. Diploid Cyanococcus hybrids with both $V$. arboreum and $V$. stamineum were highly sterile, except that $V$ darrowii $\times V$. arboreum $\mathrm{F}_{1}$ hybrids produced a few viable unreduced gametes, and a few seedlings were obtained after $F_{1}$ flowers were pollinated with pollen from tetraploid highbush cultivars (Brooks and Lyrene, 1998). Diploid $V$. darrowii $\times V$. stamineum hybrids have so far been too weak to permit backcrosses to tetraploids.

At the tetraploid level, most $F_{1}$ hybrids of both types are partially fertile, with much variation in fertility among individual $F_{1}$ plants. Average percent well-formed pollen grains averaged $39.7 \%$ for 86 highbush $\times$ tetraploid $V$. arboreum $\mathrm{F}_{1}$ seedlings (Lyrene, 2013) and $30.9 \%$ for 33 highbush $\times$ tetraploid $V$. stamineum $\mathrm{F}_{1}$ seedlings. In seedling populations produced by backcrossing a diverse population of $F_{1}$ hybrids of each type to highbush cultivars, percent good pollen averaged $70.3 \%$ for $V$. arboreum backcrosses and $62.7 \%$ for $V$. stamineum. Similarities between the two types of crosses were more striking than the differences. In both cases, the most fertile tetraploid $F_{1}$ hybrids were fertile enough to allow easy production of thousands of $\mathrm{BC}_{1}$ seedlings. In both cases, the resulting $\mathrm{BC}_{1}$ hybrids averaged much higher in fertility than their $F_{1}$ parents.

Taken together, the results of these crosses and backcrosses support the conclusion suggested by previous anthocyanin data: $V$. stamineum is not as closely related to highbush blueberry as is $V$. arboreum. Both $\mathrm{F}_{1}$ and $\mathrm{BC}_{1}$ seedlings in blueberry hybrids with $V$. stamineum tend to be weaker than blueberry hybrids with $V$. arboreum. The widespread leaf bronzing in most highbush $\times V$. stamineum $\mathrm{F}_{1}$ hybrids is not seen in highbush $\times$ V. arboreum hybrids.

Implications for further Vaccinium intersectional crosses. Interest in using intersectional crosses in breeding Vaccinium cultivars is increasing. Vander Kloet and Dickinson (2009) divided the world's $\approx 400$
Vaccinium species into 30 sections. Vaccinium sections vary greatly in how closely they are related to each other. As a consequence, the results reported here for Cyanococcus crosses with sections Polycodium and Batodendron may have limited value in predicting what will happen when other intersectional crosses are attempted. The first intersectional Vaccinium cross made on a large scale and studied in great detail was made by Rousi (1963) in Finland between highbush cultivars and Vaccinium uliginosum (Vaccinium section Vaccinium). Thousands of $F_{1}$ and backcross seedlings were grown, and the cold-hardy cultivar Aron was selected. 'Aron' was recommended for hobby cultivation in southern Finland, but was not considered sufficiently productive for commercial blueberry production (Rousi, 1963; Hiirsalmi, 1989).

Tsuda et al. (2013) produced fertile hybrids by crossing colchicine-induced tetraploid Vaccinium bracteatum (section Bracteata), which is native in Japan, with the highbush cultivar 'Spartan'. The hybrids were expected to be useful in breeding cultivars with higher sugar content, abundant phytochemicals, extensive environmental adaptability, and late flowering and fruit maturity.

Blueberry breeders have been interested in crossing highbush cultivars with bilberry, Vaccinium myrtillus (section Myrtillus), a diploid, low-growing, rhizomatous species native in the British Isles and in parts of northern Europe (Ritchie, 1956). Bilberries are valued for their small, acid berries which have purple flesh and high levels of anthocyanin in both skin and flesh. Large quantities of bilberries are gathered annually from the forest and sold in European markets. Bilberry hybrids have been produced that combine genes from other Vaccinium sections, but so far these crosses have not led to cultivars.

\section{Literature Cited}

Allard, R.W. 1960. Principles of Plant Breeding. Wiley, New York, NY.

Ashe, W.W. 1931. Polycodium. J. Elisha Mitchell Sci. Soc. 46:196-213.

Baker, P.C. 1970. A systematic study of the genus Vaccinium L. subgenus Polycodium (Raf.) Sleumer in the southeastern United States. Univ. North Carolina at Chapel Hill, NC, PhD Diss.

Ballington, J.R. 1995. The deerberry (Vaccinium stamineum L. Vaccinium section Polycodium (Raf.) Sleumer): A potential new small fruit crop, p. 21-28. In: R.E. Gough and R.F. Korcak (eds.). Blueberries: A century of research. Haworth Press, Inc., New York, NY.

Ballington, J.R., W.E. Ballinger, W.H. Swallow, G.J. Galletta, and L.J. Kushman. 1984. Fruit quality characterization of 11 Vaccinium species. J. Amer. Soc. Hort. Sci. 109:684-689.

Ballinger, W.E., E.P. Maness, and J.R. Ballington. 1982. Anthocyanins in ripe fruit of the sparkleberry, Vaccinium arboreum Marsh. Can. J. Plant Sci. 62:683-687.

Brooks, S.J. and P.M. Lyrene. 1998. Derivatives of Vaccinium arboreum $\times$ Vaccinium section Cyanococcus. II. Fertility and fertility parameters. J. Amer. Soc. Hort. Sci. 123:997-1003.

Camp, W.H. 1945. The North American blueberries with notes on other groups of Vacciniaceae. Brittonia 5:203-275.

Cane, J.H., G.C. Eickwort, F.R. Wesley, and J. Spielholz. 1985. Pollination ecology of $\mathrm{Vacci}$ nium stamineum (Ericaceae: Vaccinioideae). Amer. J. Bot. 72:135-142.

Darrow, G.M. and W.H. Camp. 1945. Vaccinium hybrids and the development of new horticultural material. Bull. Torrey Bot. Club 72:1-21.

Darwin, C. 1859. On the origin of species. John Murray, Kent, London, UK.

Hiirsalmi, H.M. 1989. Research into Vaccinium cultivation in Finland. Acta Hort. 241:175184.

Luteyn, J.L., W.S. Judd, S.P. Vander Kloet, L.J. Dorr, G.D. Wallace, K.A. Kron, P.S. Stevens, and S.E. Clemants. 1996. Ericaceae of the southeastern United States. Castanea 61:101144.

Lyrene, P.M. 1989. Pollen source influences fruiting of 'Sharpblue' blueberry. J. Amer. Soc. Hort. Sci. 114:995-999.

Lyrene, P.M. 2013. Fertility and other characteristics of $F_{1}$ and Backcross $s_{1}$ progeny from an intersectional blueberry cross ((highbush cultivar $\times$ Vaccinium arboreum $) \times$ highbush cultivar). HortScience 48:146-149.

Lyrene, P.M. 2016. Phenotype and fertility of intersectional hybrids between tetraploid highbush blueberry and colchicine-treated $\mathrm{Vacci}$ nium stamineum. HortScience 51:15-22.

Ritchie, J.C. 1956. Vaccinium myrtillus L. J. Ecol. 44:291-299.

Rousi, A. 1963. Hybridization between Vaccinium uliginosum and cultivated blueberry. Ann. Agr. Fenn. 2:12-18.

Stebbins, G.L. 1950. Variation and Evolution in Plants. Columbia Univ. Press, New York, NY.

Tsuda, H., H. Kunitake, M. Yamasaki, H. Komatsu, and K. Yoshioika. 2013. Production of intersectional hybrids between colchicine inducedtetraploid shashanbo ( $V$. bracteatum) and highbush blueberry 'Spartan'. J. Amer. Soc. Hort. Sci. 138:317-324.

Uttal, L.J. 1987. The genus Vaccinium L. in Virginia. Castanea 52:231-255.

Vander Kloet, S.P. 1988. The genus Vaccinium in North America. Publ. 1828. Agriculture Canada.

Vander Kloet, S.P. and T.A. Dickinson. 2009. A subgeneric classification of the genus $\mathrm{Vacci}$ nium and the metamorphosis of $V$. section Bracteata Nakai: More terrestrial and less epiphytic in habit, more continental and less insular in distribution. J. Plant Res. 122:253268. 